\title{
How Do African Firms Respond to Unreliable Power? Exploring Firm Heterogeneity Using K-Means Clustering
}

\section{Vijaya Ramachandran, Manju Kedia Shah, and Todd Moss}

\section{Abstract}

In this paper, we apply a novel analytical technique- $\mathrm{k}$-means clustering — to understand the relationship between the growth of firms and the availability of power in sub-Saharan Africa. We develop a classification of firms and show how firm clusters are distributed across industries and countries. Our analysis reveals a surprising degree of within-country heterogeneity in the experience of firms. While previous studies have found a positive relationship between the reliability of power and firm growth, we find that such a clear relationship seems not to prevail. In other words, some firms are able to cope with an unreliable supply of power while many others do not. This may be because firms self-select into industries which promise high returns despite anticipated power problems. Further research on the conditions determining entry would provide insight into why some firms succeed in a poor business environment, while others are unable to thrive.

Keywords: electricity, power outages, Africa, firm growth, industrialization

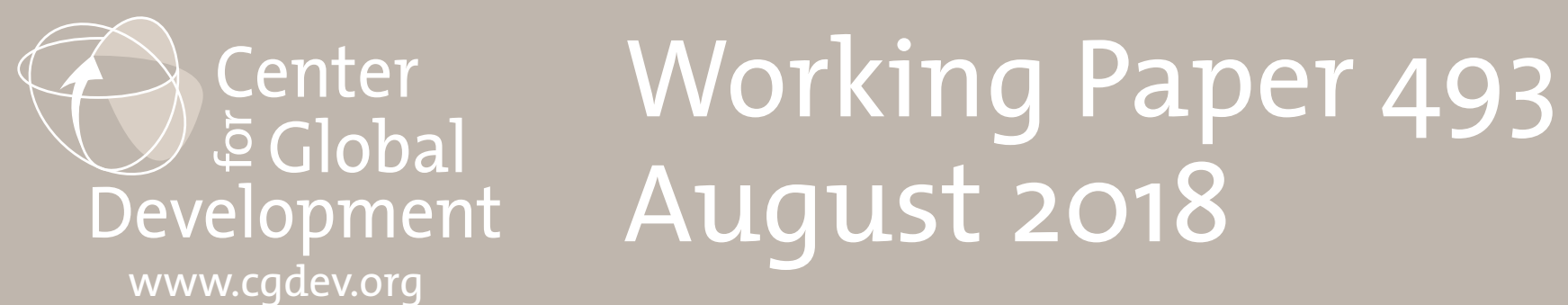




\title{
How Do African Firms Respond to Unreliable Power? Exploring Firm Heterogeneity Using K-Means Clustering
}

\author{
Vijaya Ramachandran \\ Center for Global Development \\ Manju Kedia Shah \\ Campbell University \\ Todd Moss \\ Center for Global Development
}

The authors would like to thank Alan Gelb, an anonymous external reviewer, and seminar participants at the Breakthrough Dialogue 2018 for helpful comments and suggestions. Gailyn Portelance and Divyanshi Wadhwa provided excellent research assistance.

The Center for Global Development is grateful for contributions from the Rockefeller Foundation and the Australian Department of Foreign Affairs and Trade in support of this work.

Vijaya Ramachandran, Manju Kedia Shah, and Todd Moss, 2018. "How Do African Firms Respond to Unreliable Power? Exploring Firm Heterogeneity Using K-Means Clustering." CGD Working Paper 493. Washington, DC: Center for Global Development. https://www.cgdev.org/publication/how-do-african-firms-respond-unreliable-powerexploring-firm-heterogeneity-using-k-means

Center for Global Development 2055 L Street NW Washington, DC 20036

202.416.4000

(f) 202.416 .4050

www.cgdev.org
The Center for Global Development works to reduce global poverty and improve lives through innovative economic research that drives better policy and practice by the world's top decision makers. Use and dissemination of this Working Paper is encouraged; however, reproduced copies may not be used for commercial purposes. Further usage is permitted under the terms of the Creative Commons License.

The views expressed in CGD Working Papers are those of the authors and should not be attributed to the board of directors, funders of the Center for Global Development, or the authors' respective organizations. 


\section{Contents}

Introduction: Unreliable Power in Sub-Saharan Africa ......................................................... 1

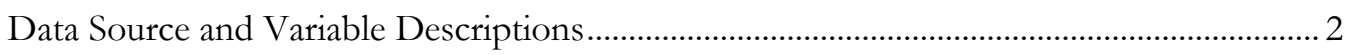

Measuring the Impact of Unreliable Power: K-Means Clustering ........................................... 7

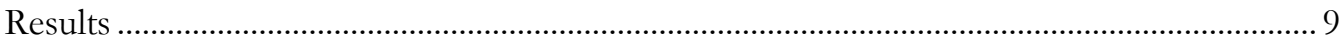

Further Analysis: What Factors Drive Job Creation in Some Firms? .....................................15

Conclusion: Clustering Highlights the Varied Experiences of Firms in Africa......................18

Appendix 1: A Sample of the Literature on Electricity Access................................................19

Literature Reviews ……………………………………...................................................19

Notable Sample Cross-Country Research using World Bank Enterprise Surveys...........19

Sample of Recent Specific Country Research Using World Bank Enterprise

Surveys and Other Databases ............................................................................................2 


\section{Introduction: Unreliable Power in Sub-Saharan Africa}

Electricity remains in short supply in almost every African country. Almost 600 million people in sub-Saharan Africa lack access to electricity at home. Most of the region has an average grid access rate of just 20 percent, while only seven countries-Cameroon, Côte d'Ivoire, Gabon, Ghana, Namibia, Senegal and South Africa-have household electricity access rates exceeding 50 percent.

While lack of basic household access is a widespread concern, problems of electricity cost and reliability for commercial and industrial purposes can have potentially devastating effects on job creation, firm productivity, and income growth. In many countries, for example, diesel generators are relied upon to provide electricity for business, by, with prices for power ranging from three to six times the price of grid-provided electricity. Several researchers have demonstrated the relationship between the cost of unreliable electricity and firm productivity (Abotsi, 2016; Ramachandran et al, 2009). Much of this work has used firm-level data to show that costly and/or unreliable power has significantly negative impacts on the private sector. Most recently, Cole et al (2018) argue that reducing outage levels to those of South Africa would increase overall sales of firms in sub-Saharan Africa by 85 percent. Mensah (2018) found that electricity shortages reduced the likelihood of employment by 35-41 percent. (See Appendix 1 for a description of some of these papers and their results.)

While reducing power costs and outages are likely to have positive benefits for firms, there are many unanswered questions. In this paper, we ask-which countries might benefit the most from improved power? And what kinds of firms? Do all firms in sub-Saharan Africa face similar problems? Would all firms produce more or grow faster if they had fewer outages?

We begin with the premise that the cost and burden of outages is felt by some more than others, at the firm, sector and country level. We explore these differences using a methodology known as K-means clustering which sorts firms on multiple dimensions including various measures of unreliable power.

Let us consider a simple schematic that describes the role of power in driving firm productivity and job creation. Figure 1 describes the factors driving supply and demand within a firm. Increasing demand for the company's product is a necessary condition for growth while supply costs and bottlenecks impact actual outcomes for the firm. The cost of unreliable electricity (as reflected by power outages) is a subset of costs impacting production. However, costs are interlinked. For example, firms cannot use technology without reliable power. Firms cannot purchase generators without financial capital. 
Figure 1. Factors driving job creation in African enterprises

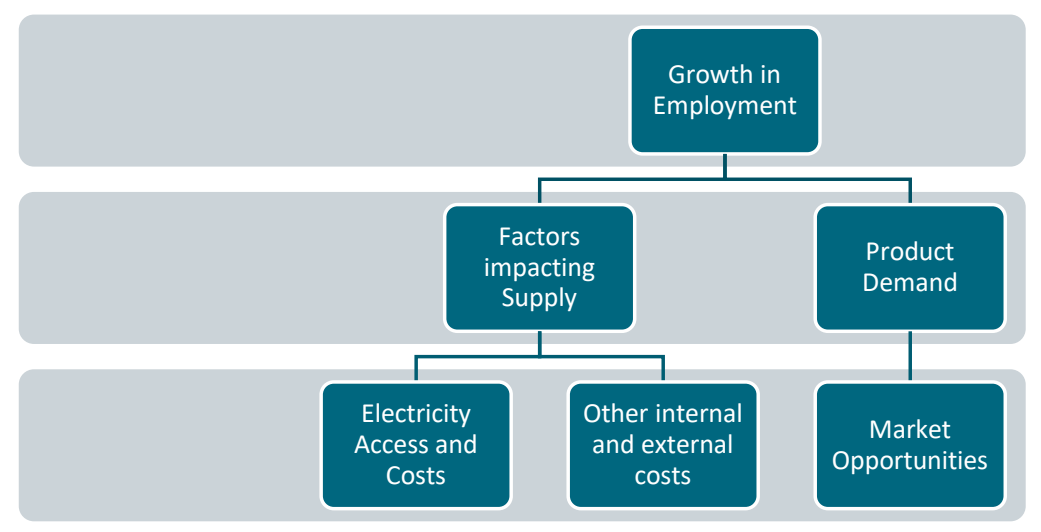

The aggregate costs of unreliable power are well-established. However, less is known about individual firm experiences. Do some firms face a higher burden compared to others? Do generators offset the adverse impact of unreliable power for some firms and not others? Do firms that report higher outages all grow slower than others, or is this a diverse group? Do all firms in countries with known problems in public supply of electricity all report severe problems with outages and associated costs? We try to answer these questions.

\section{Data Source and Variable Descriptions}

The World Bank Enterprise Surveys offer firm-level data collected through face to face interviews for a representative sample of an economy's private sector. The surveys cover a broad range of business environment topics including access to finance, corruption, infrastructure, crime, competition, and performance measures. The entire dataset is available at www.enterprisesurveys.org.

Using a sample of 3109 firms from 37 African countries, we examine the cost of unavailable or unreliable power for firms with 10 or more employees, by focusing on the following questions that capture the extent of the electricity problem:

(1) Has the firm experienced power outages in the past fiscal year?

(2) If yes, how many outages does a firm experience in a typical month?

(3) What is the average duration of these outages?

(4) What percent of sales are lost due to power outages?

(5) Does the firm use an own/shared generator?

(6) Is electricity a major constraint to firm operations?

Figure 2 shows the average number of outages per month and the corresponding duration of an outage experienced by firms in 37 African countries. We immediately see that lack of clear correlation between number of outages and duration of an outage - countries such as Mauritania and Madagascar, for example, report an average of about 8 outages a month, but with each outage lasting less than two hours. On the other hand, firms in Sierra Leone and Burkina Faso report almost the same-about nine outages a month, but with each outage 
lasting more than four hours, twice that of firms in Mauritania and Madagascar. Some countries such as Central African Republic, Benin, Chad, Nigeria have high frequency and long duration in outages, and are at the high end of the spectrum in electricity costs to businesses, while the middle income countries in SSA are at the low end of the spectrum, with negligible outages. While there is no clear correlation it is interesting that there does seem to be a break around the outage level of 8 outages per month, with countries above this generally experiencing long outages and those below having more varied experiences.

Figure 2. Average outages in a month (left panel) and the corresponding average hours per outage (right panel)

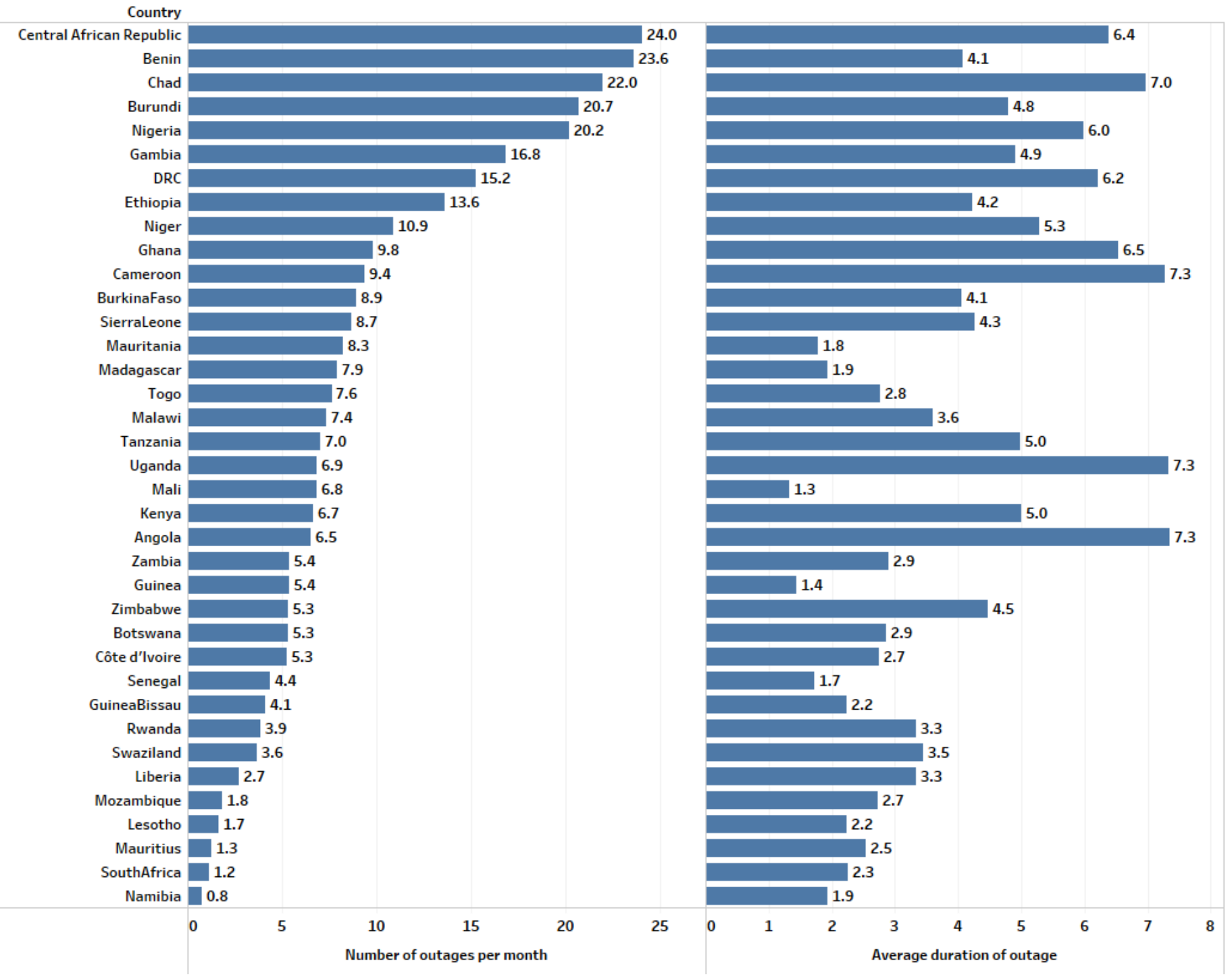


Figure 3 presents the percentage of sales lost due to outages, and the percentage of firms owning a generator. A priori, we would expect losses to be lower in countries which have either a reliable electricity supply, or where majority of firms have generators. However, this is not the case-we see some countries where like Angola, Central African Republic and Nigeria where firms report more than 10 percent of sales lost due to outages, despite more than three quarters of firms owning generators.

Figure 3. Percentage of sales lost due to outage (left panel) and the corresponding percentage of firms with generator (right panel)

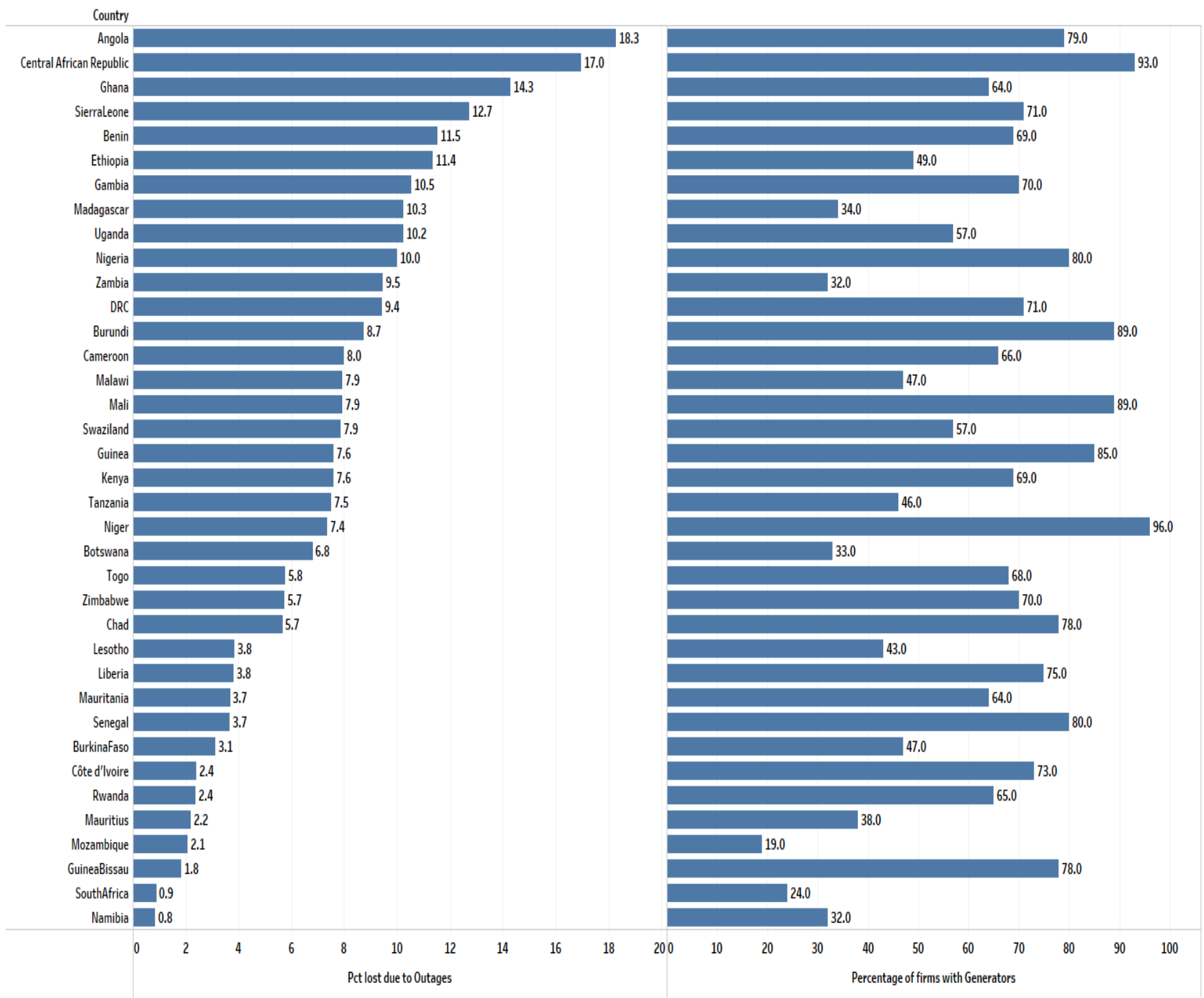


A closer look at firm level data shows large variation in responses within each country, including countries with very unreliable electricity infrastructure.

Figure 4 presents box plots showing the range of responses for number of outages in a month, while figure 5 presents box plots for percentage lost due to outages. We see that country averages mask the wide variation-in almost all countries, there are firms that report very few outages; likewise, there are firms that report minimal losses in sales due to outages, even in countries such as Central African Republic, Nigeria, Uganda and others. On the other end of the spectrum, we see several large outliers, with firms reporting multiple outages daily, and some firms reporting losses as high as 70 percent of sales.

\section{Figure 4. Within-country dispersion in number of outages reported in a typical month}

Country

\section{0}

90

80

70

证

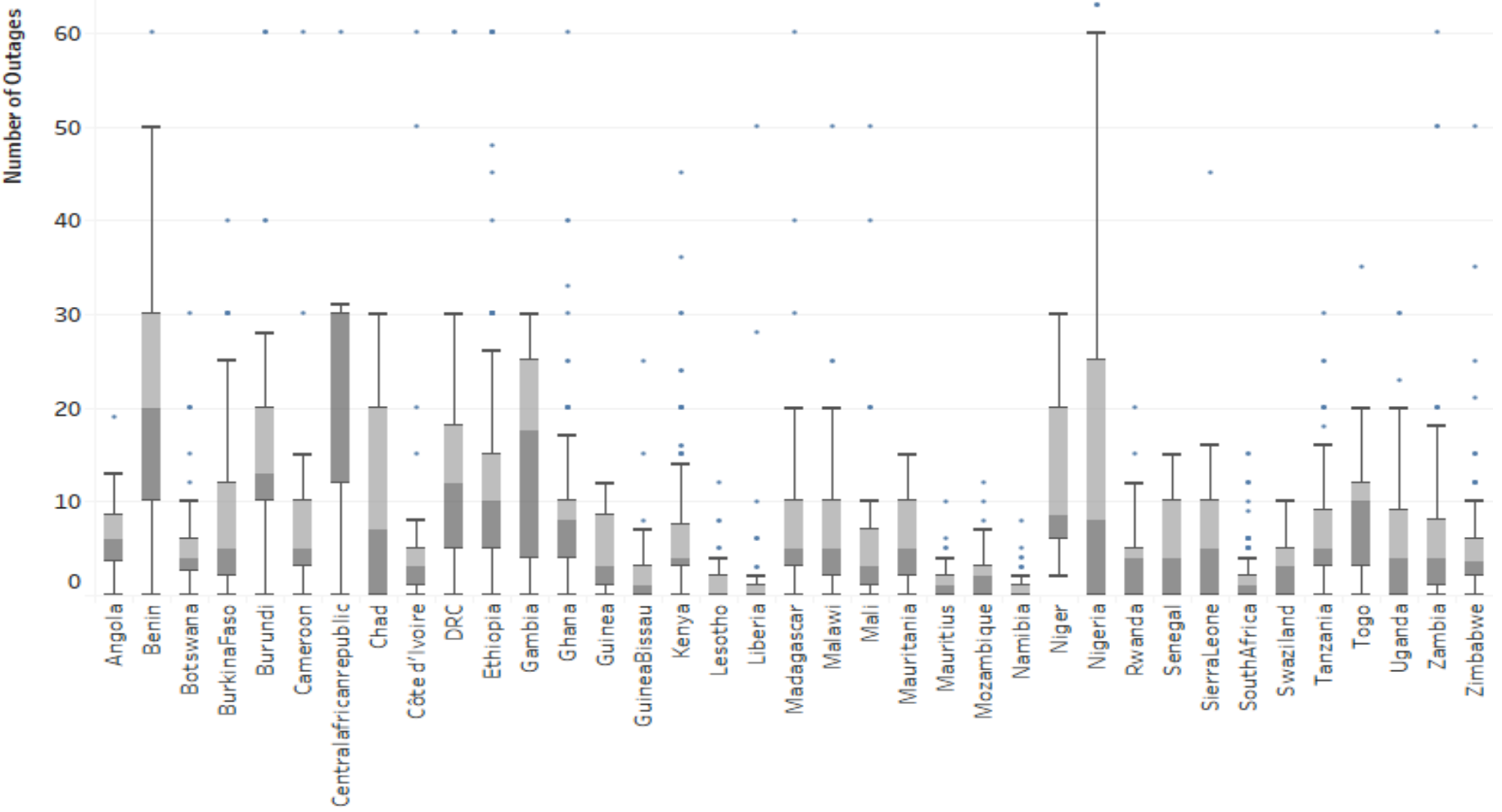


Figure 5. Percentage of sales lost due to outages

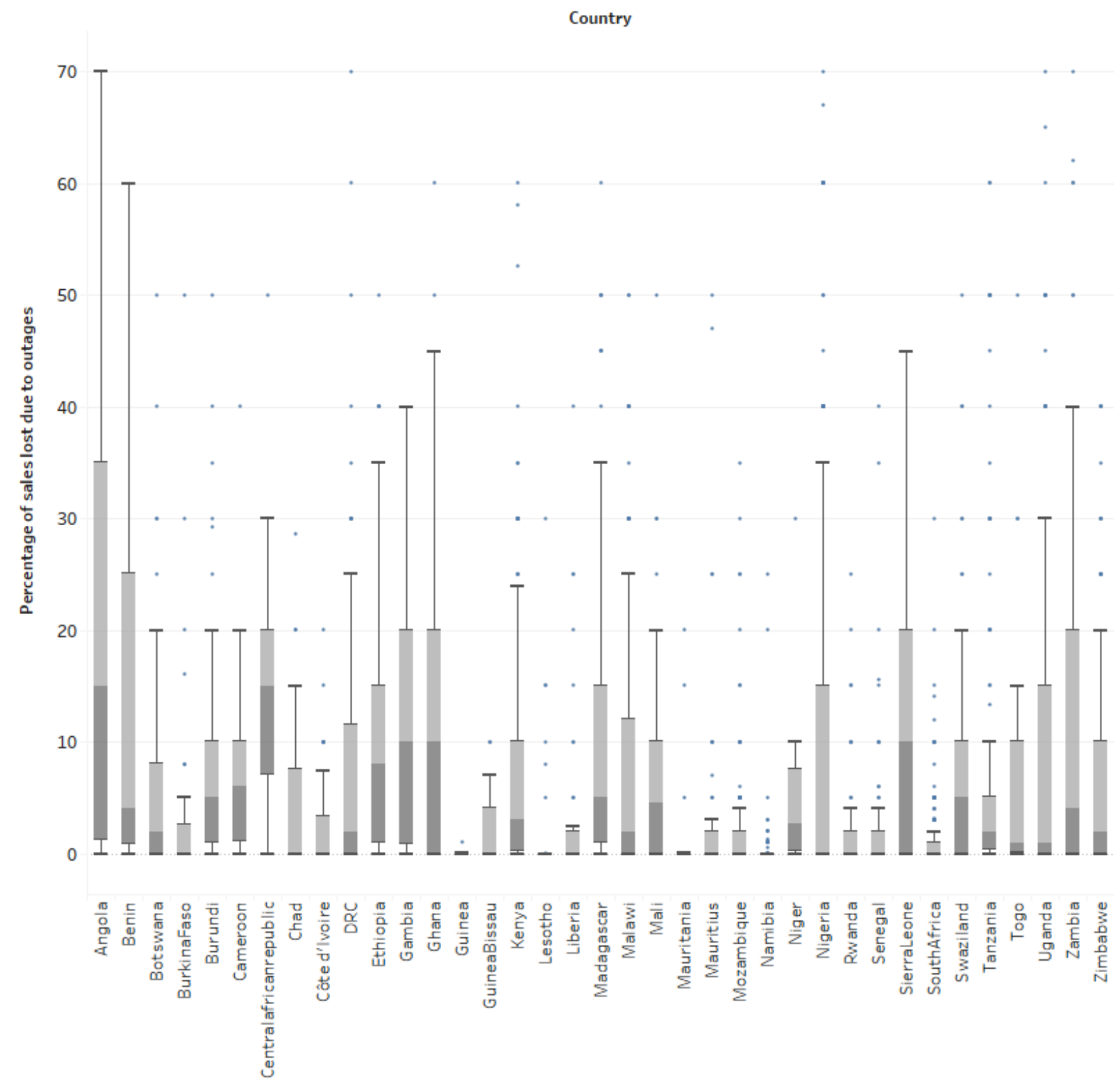




\section{Measuring the Impact of Unreliable Power: K-Means Clustering}

The data presented above indicate that even in better-performing countries, firms can face high electricity costs, while some firms, even in countries with very poor electricity provision, can face a low burden of electricity costs and losses. This prompts us to investigate the impact of electricity provision on performance at the enterprise level, rather than focusing on country level averages.

Previous studies have examined the impact of electricity shortages and use of generators on performance using multivariate regression analysis. These studies show the positive impact of generator use on firm productivity and growth, and the inverse relationship between outages reported and firm performance.

Our study takes a different approach. Instead of establishing a causal and specific functional relationship between electricity costs and enterprise growth, we simply examine natural groupings of firms in sub-Saharan Africa, based on their reported experiences. If the relationship between outages, losses and growth is linear, a priori, we would expect to see groups of firms that report few outages to experience higher growth. At the other end of the spectrum, we would expect to see groups of firms that report significant losses to also have low growth rates. Since generators offset the electricity problem, we would expect to see firms with generators report lower losses and experience higher growth.

This approach — clustering — is a widely used data mining method with various applications in industry and research. It is used to identify groups of customers for targeted marketing, in-text mining, and in geospatial analysis, image identification and so on. In this paper, we use a particular type of clustering called $k$-means clustering.

$\mathrm{K}$-means is a clustering algorithm which partitions a set of observations $\left\{\mathbf{x}_{1}, \mathbf{x}_{2}\right.$, $\left.\ldots, \mathbf{x}_{\mathrm{n}}\right\}$, where $\mathbf{x}_{i}=\left(x_{i 1}, x_{i 2}, \ldots, x_{i r}\right)$ is a vector in a real-valued space $X \subseteq R^{r}$, and $r$ is the number of attributes (dimensions) in the data. The algorithm partitions the data into $\mathrm{k}$ clusters. It begins by assigning a centroid or cluster mean to each of the $\mathrm{k}$ clusters. Based on the Euclidean distance between each observation and the centroid, $K$-means clustering iteratively partitions $n$ observations into $k(\leq n)$ sets $\mathbf{S}=\left\{S_{1}, S_{2}, \ldots, S_{k}\right\}$ so as to minimize the within-cluster sum of squares (variance) of the distance between $\mathbf{x}_{i}$ and the centroid. Each iteration determines both the number of firms in the cluster as well as the value of the centroid. This process is equivalent to minimizing the pairwise squared deviations of points within a cluster. As total variance is constant, this is also equivalent to maximizing the squared deviations between points in different clusters (i.e. between-cluster sum of squares). The k-means clustering technique stops at the point where it finds the lowest within-group variance, and the highest between-group variance.

We use k-means clustering to identify enterprise groups: which firms are similar to each other in their experiences with outages, losses, generator use and job growth? Which ones are least like each other? To keep the exercise manageable, we define the vector $\mathbf{x}_{i}$ to consist of five key variables upon which the clustering algorithm is applied: 
- Total hours of power outage per month — computed by multiplying average number of outages with hours per outage. Ranges between 0 and 240 hours

- Generator use: A binary variable measuring use of generator

- Percentage of sales lost due to outages. Ranges between 0-100 percent

- Two-year growth rate: Logarithmic growth rate between employment three years back and current employment. Ranges between 52 percent to 66 percent

- Firm size: Total current employment. Ranges between 10-1200 workers

All variables are standardized to ensure balanced weights.

The optimal number of clusters is determined by a process known as the Elbow method. The elbow method determines the optimal number of clusters by examining the withincluster variance explained as a function of the number of clusters: the optimal number of clusters is such that adding another cluster leads to a negligible decrease in variation. A plot of the within-cluster variance explained by the clusters against the number of clusters shows the decline of within-cluster variance with the number of clusters-at some point the marginal gain will fall significantly-the "elbow" in the graph. The number of clusters is chosen at or close to this point. Figure 6 shows the pattern of within-cluster variance for our dataset of 3109 firms across the five dimensions specified above. We see the variance "elbows" at between six to seven clusters. We choose $\mathrm{k}$ as 6 , as additional declines in withincluster variance are not significant in magnitude. 
Figure 6. Cluster determination using the Elbow method

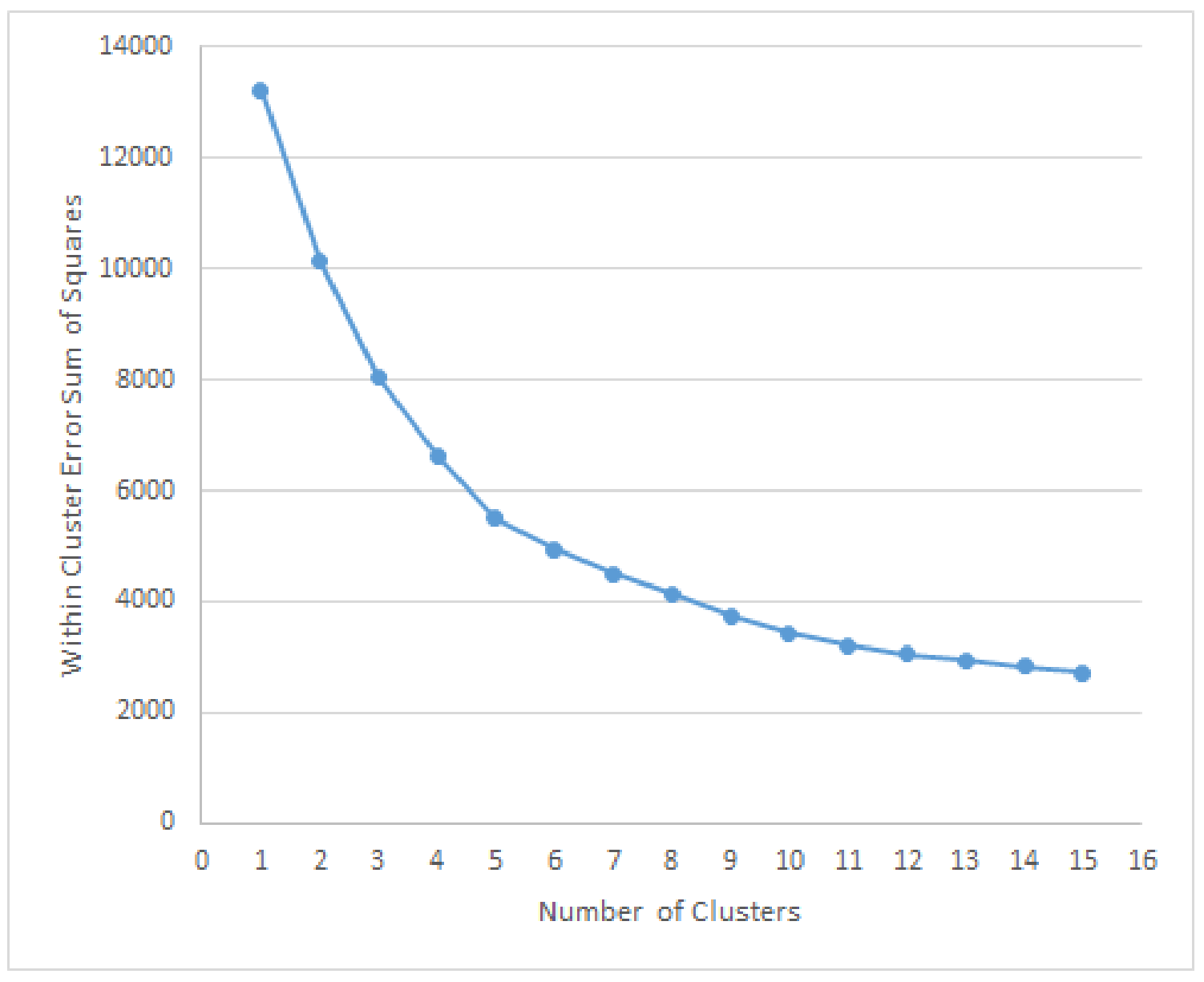

\section{Results}

The k-means clustering technique results in six clusters in our sample of 3109 firms.

Marchers: Cluster 1 contains large firms with moderate electricity costs; many firms own generators. These firms are spread across Africa with a higher share in east and southern Africa. These firms are "marchers"-firms that have a decent rate of growth in employment (8 percent) despite experiencing 25 hours of power outages per month.

Plodders: Cluster 2 are firms have a relatively steady supply of power, with only 11.45 hours of power outages per month. They lose hardly any sales to outages and none of them own generators. These firms have grown at 5 percent a year over the past two years. Plodders are mostly located in middle income countries.

Racers: Cluster 3 is perhaps the most interesting of our clusters. These firms are growing rapidly, roughly doubling in size over two years. With a median firm size of 59 workers, they do suffer some power outages but have managed to cope with unreliable power. About half of the firms in this group own generators, and the percentage of sales lost due to power outages is only 5.31 percent. There are 286 firms in this cluster, spread all over the African 
continent, including in very poor countries. About a quarter of all firms in Chad and Liberia belong to this cluster. Almost 16 percent of firms in Nigeria are in this cluster.

Survivors: Cluster 4 represents a large cluster of 1015 firms that are growing very slowly. These firms report a growth rate of about 3 percent per year. These firms are to be found all over Africa with a particularly high share in Niger (100 percent), Mauritania (72 percent), Guinea Bissau (72 percent) and Mali (61 percent). About half of all firms in Zimbabwe also belong in this cluster.

Non-Adaptors: Cluster 5 contains a group of 352 firms that report very high losses due to power outages. Almost one in five firms in Ethiopia and Uganda fall into this group, and more than one-third of firms in Angola are located here. These firms grow at 4 percent per year and while more than half own generators, this does not seem to compensate for the 52 hours of power outages suffered per month. These firms lose 31 percent of sales due to power outages!

Strugglers: Finally, firms in Cluster 6 face the highest outages (218 hours per month) and report that 15 percent of their sales are lost due to these outages. More than three quarters own generators. Half of all firms in the Central African Republic are in this cluster along with a quarter of all firms in Nigeria and Chad.

Figures 7-12 describe the distribution of firms by cluster and the attributes of each cluster. It highlights the fact that firms across countries face similar constraints and growth experiences, while also demonstrating how individual firm experiences can vary widely within a country. 
Figure 7.

\section{Cluster 1: Marchers}

Percentage of firms in each country

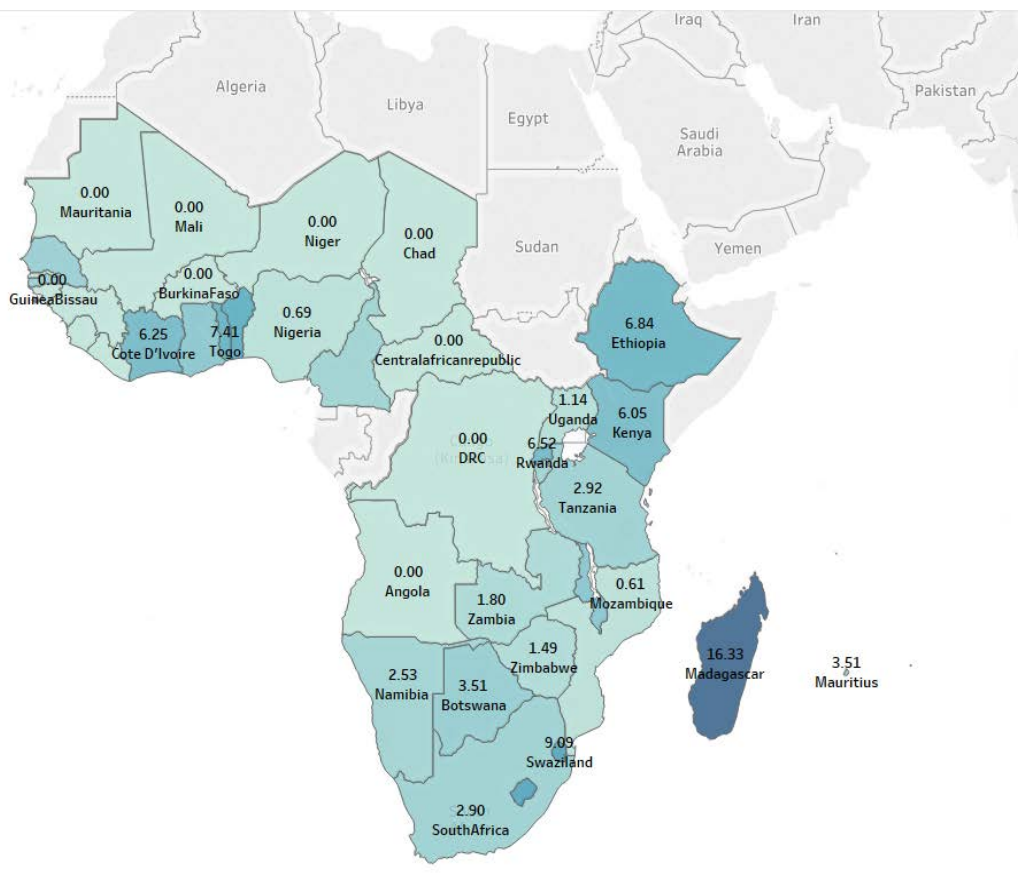

\begin{tabular}{|l|r|}
\hline \multicolumn{2}{|c|}{ Cluster 1 Averages } \\
\hline $\begin{array}{l}\text { Number of hours of } \\
\text { power outages per } \\
\text { month }\end{array}$ & 24.76 \\
\hline $\begin{array}{l}\text { Sales lost due to } \\
\text { outages }\end{array}$ & $6.81 \%$ \\
\hline $\begin{array}{l}\text { Employment } \\
\text { growth rate in past } \\
\text { two years }\end{array}$ & $8 \%$ \\
\hline $\begin{array}{l}\text { Firm size (total } \\
\text { number of workers) }\end{array}$ & 685 \\
\hline $\begin{array}{l}\text { Generator } \\
\text { ownership }\end{array}$ & $64 \%$ \\
\hline Number of firms & 106 \\
\hline
\end{tabular}

Figure 8.

Cluster 2: Plodders

Percentage of firms in each country

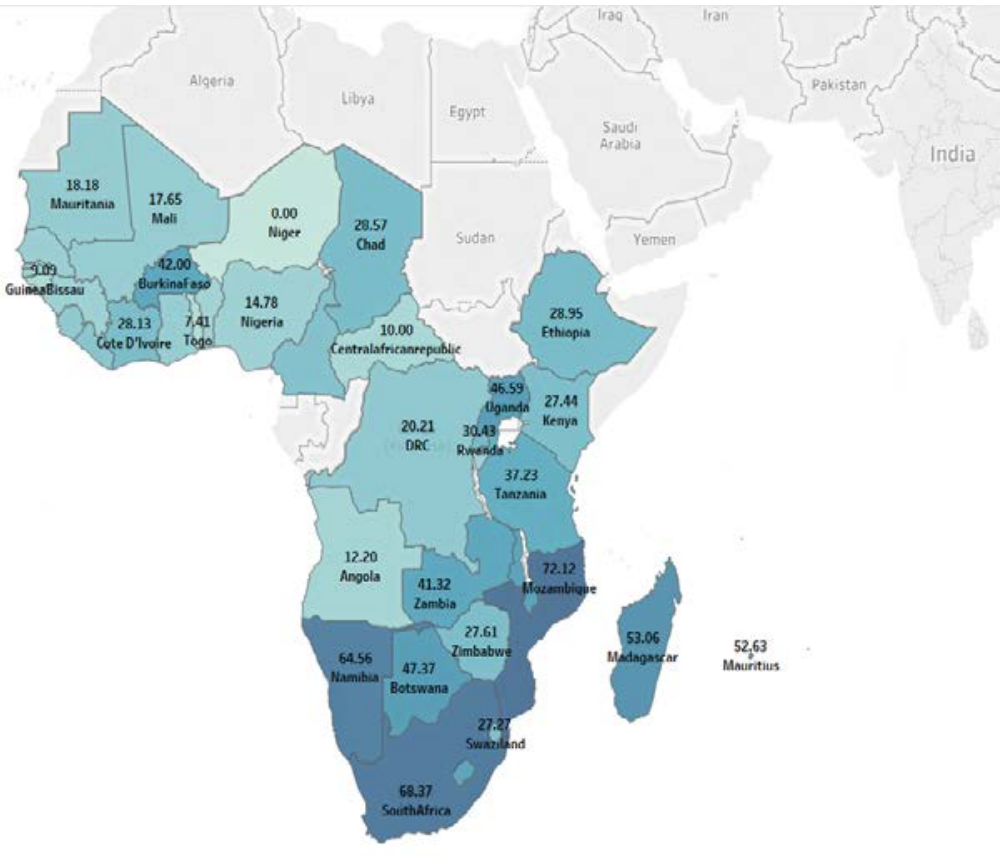

\begin{tabular}{|l|r|}
\hline \multicolumn{2}{|c|}{ Cluster 2 Averages } \\
$\begin{array}{l}\text { Number of hours of } \\
\text { power outages per } \\
\text { month }\end{array}$ & 11.45 \\
\hline $\begin{array}{l}\text { Sales lost due to } \\
\text { outages }\end{array}$ & $1.78 \%$ \\
\hline $\begin{array}{l}\text { Employment } \\
\text { growth rate in past } \\
\text { two years }\end{array}$ & $5 \%$ \\
\hline $\begin{array}{l}\text { Firm size (total } \\
\text { number of workers) }\end{array}$ & 45 \\
\hline $\begin{array}{l}\text { Generator } \\
\text { ownership }\end{array}$ & $0 \%$ \\
\hline \begin{tabular}{l} 
Number of firms \\
\hline
\end{tabular} & 1174 \\
\hline
\end{tabular}


Figure 9.

\section{Cluster 3: Racers}

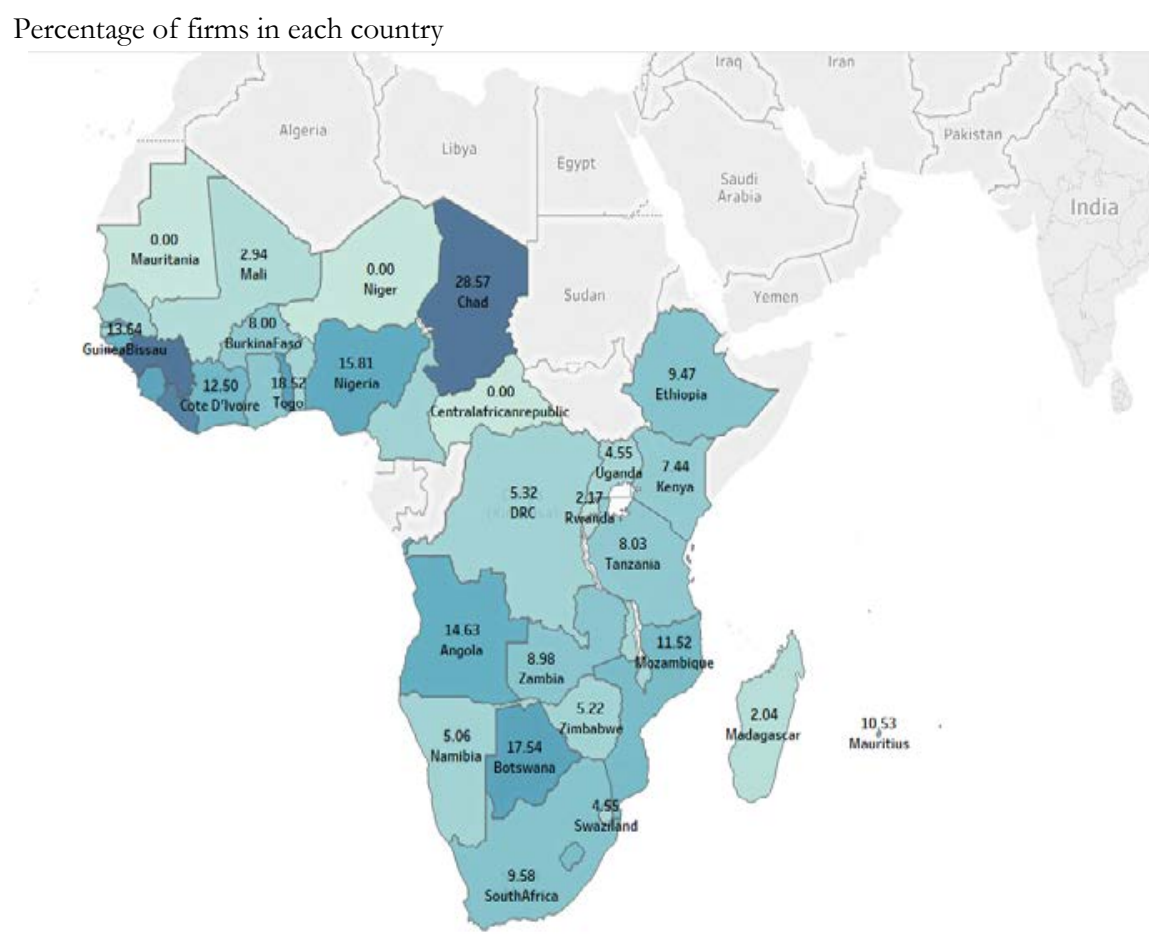

\begin{tabular}{|l|r|}
\hline \multicolumn{2}{|c|}{ Cluster 3 Averages } \\
\hline $\begin{array}{l}\text { Number of hours of } \\
\text { power outages per } \\
\text { month }\end{array}$ & 22.42 \\
\hline $\begin{array}{l}\text { Sales lost due to } \\
\text { outages }\end{array}$ & $5.31 \%$ \\
\hline $\begin{array}{l}\text { Employment } \\
\text { growth rate in past } \\
\text { two years }\end{array}$ & $52 \%$ \\
\hline $\begin{array}{l}\text { Firm size (total } \\
\text { number of workers) }\end{array}$ & 59 \\
\hline $\begin{array}{l}\text { Generator } \\
\text { ownership }\end{array}$ \\
\hline \begin{tabular}{l} 
Number of firms \\
\hline
\end{tabular} & 286 \\
\hline
\end{tabular}

Figure 10.

Cluster 4: Survivors

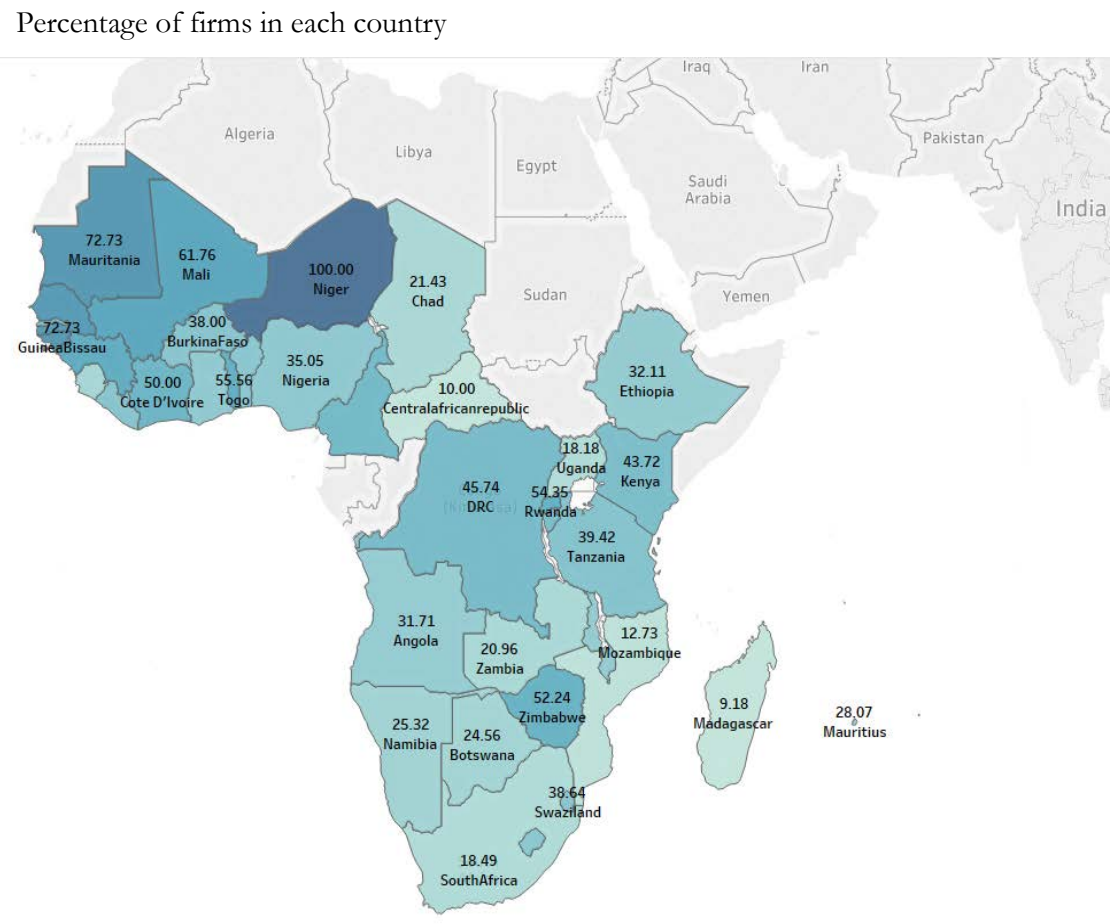

\section{Cluster 4 Averages}

Number of hours of power outages per month

Sales lost due to outages

Employment growth rate in past two years

Firm size (total number of workers)

Generator
ownership $100 \%$

Number of firms 
Figure 11.

Cluster 5: Non-Adaptors

Percentage of firms in each country

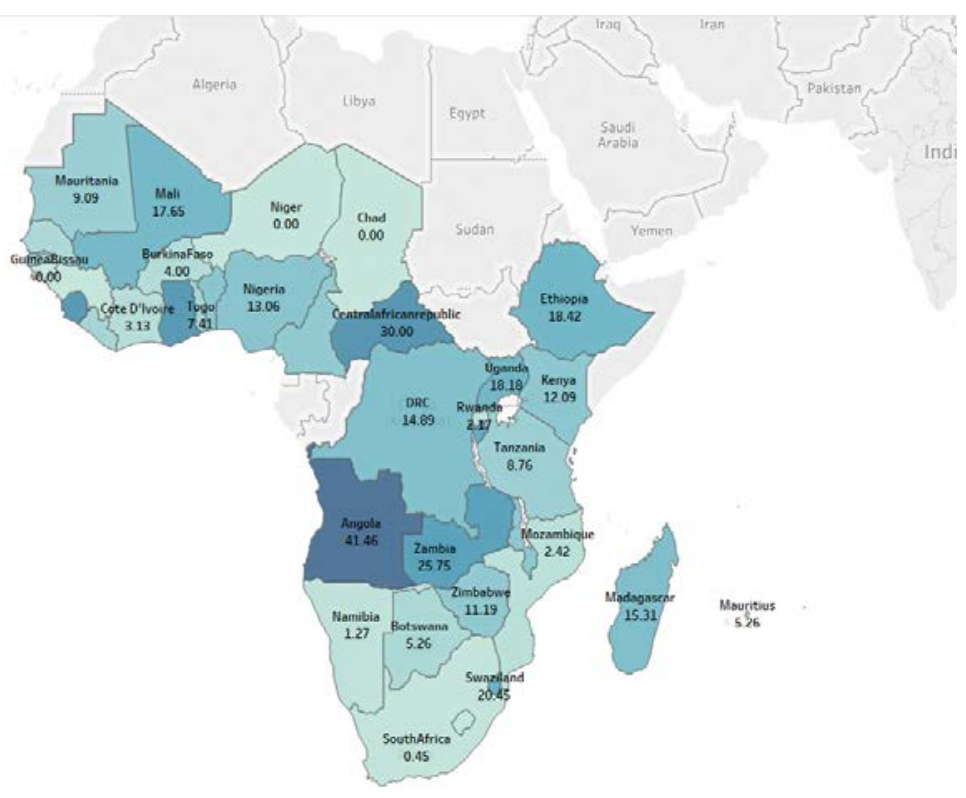

Figure 12.

Cluster 6: Strugglers

Percentage of firms in each country

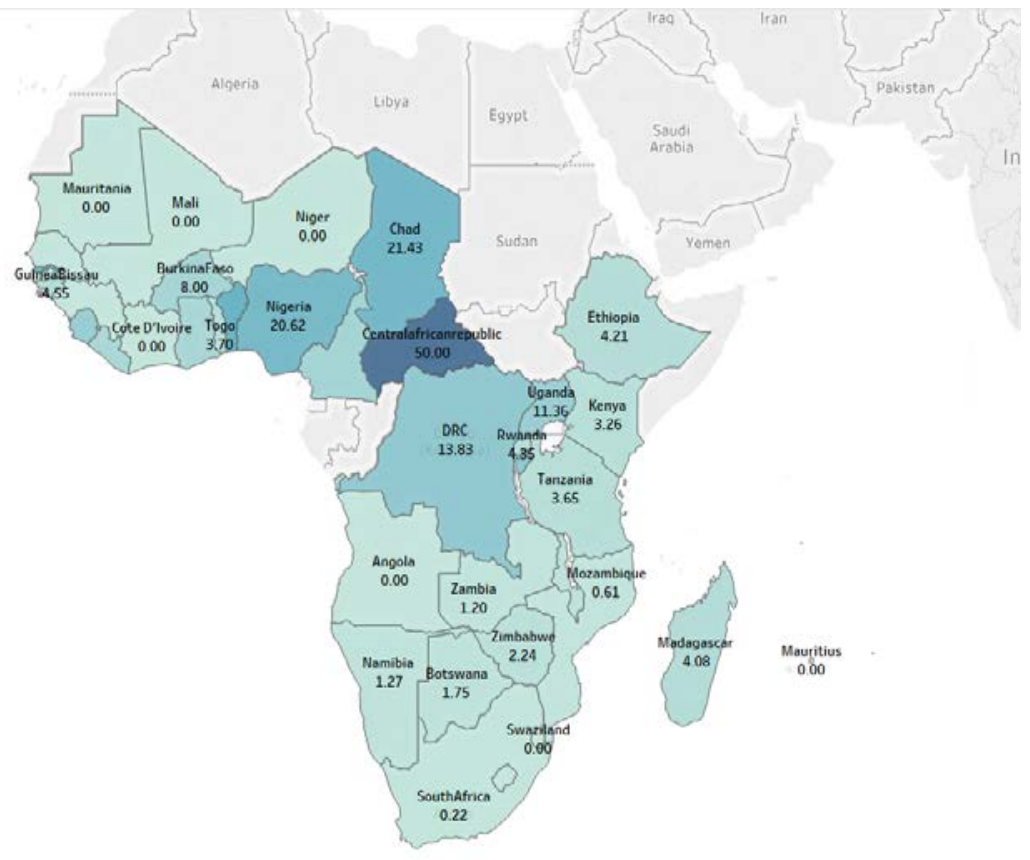

\begin{tabular}{l|r}
\multicolumn{2}{|c}{ Cluster 6 Averages } \\
$\begin{array}{l}\text { Number of hours } \\
\text { of power outages } \\
\text { per month }\end{array}$ & 218.03 \\
\hline $\begin{array}{l}\text { Sales lost due to } \\
\text { outages }\end{array}$ & $15.10 \%$ \\
\hline $\begin{array}{l}\text { Employment } \\
\text { growth rate in past } \\
\text { two years }\end{array}$ & $6 \%$ \\
\hline $\begin{array}{l}\text { Firm size (total } \\
\text { number of } \\
\text { workers) }\end{array}$ \\
\hline $\begin{array}{l}\text { Generator } \\
\text { ownership }\end{array}$ \\
\hline Number of firms & 176 \\
\hline
\end{tabular}


Figure 13 presents another view of firm clusters, showing the percentage of firms in each of the six clusters within each country. Since firms in clusters 5 and 6 report the highest losses and hours of outages, we highlight these clusters in red, while cluster 4 -the cluster where all firms own generators, yet are growing very slowly (survivors) are colored in orange. Here we can see the stark differences between countries - mostly middle income - with reliable electricity supply and others. The "red" zone countries like Gambia, Central African Republic, Nigeria and Angola have more than a quarter of firms facing severe electricity problems. These red zones are virtually non-existent in countries like South Africa, Namibia, and Mauritius.

Figure 13.

Distribution of firms by cluster within each country

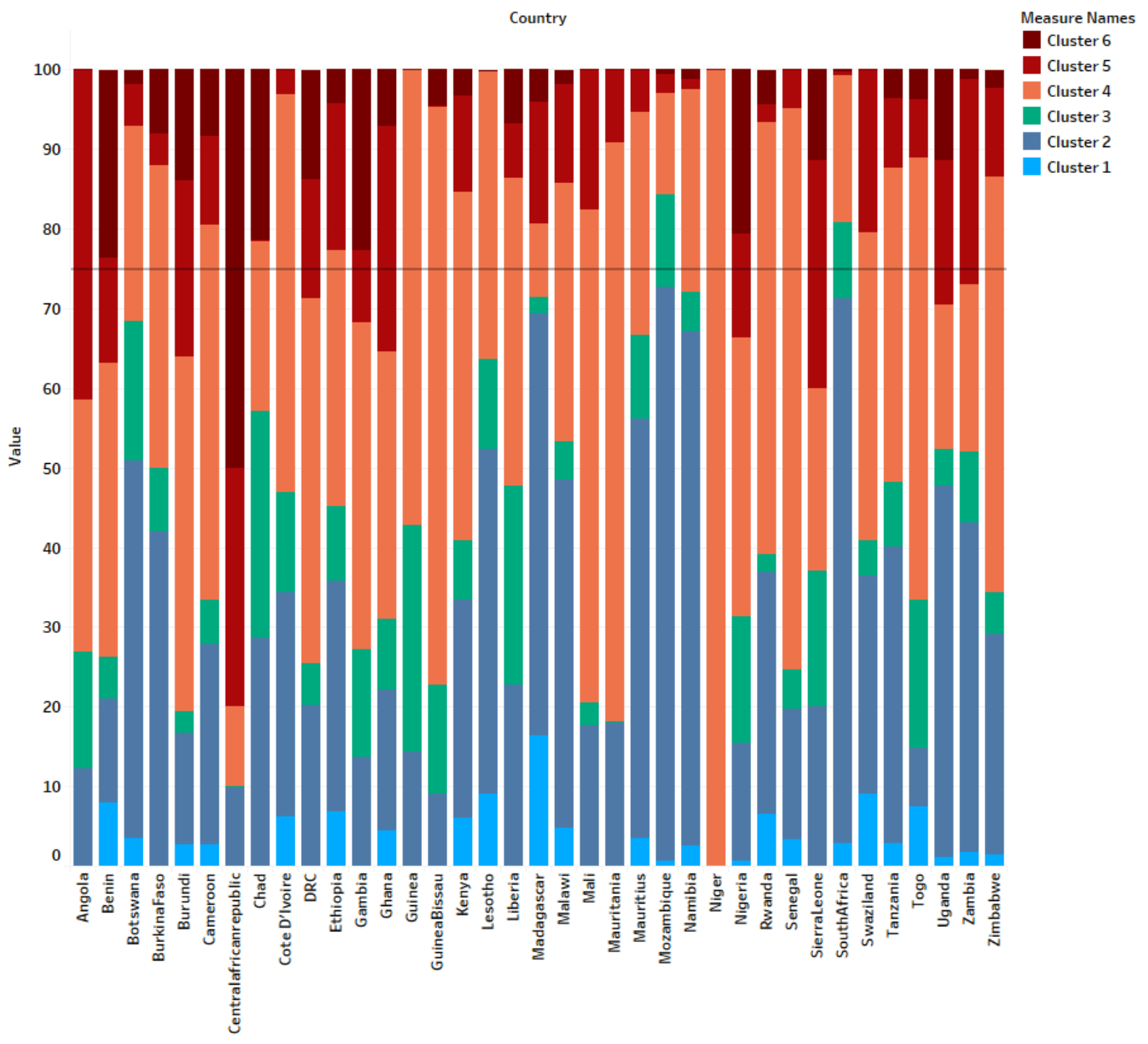




\section{Further Analysis: What Factors Drive Job Creation in Some Firms?}

The clustering analysis revealed a small, yet very interesting cluster of firms in unexpected places. We see firms in Cluster 3 averaging more than 50 percent growth over the past two years, and these firms are spread out all across sub-Saharan Africa, not simply located in countries with a reliable electricity infrastructure. The firms are mostly medium sized, and only about half own a generator. So, what drives rapid job creation in these firms?

Prior studies in enterprise growth have shown that (we can add our study here), after controlling for initial firm size and firm age, key drivers of growth are human and financial capital. Are the same factors driving these extremely high growth rates? Can we explain differences in growth rate of firms in this cluster compared to others by features such as initial size, age, human capital and financial capital? How do outages and generator ownership factor in?

We explore this using a logistic regression framework. Results show that number of outages and percentage losses are not significant-in addition to initial size and age, firms that have grown rapidly are significantly more likely to use email and have banking overdrafts. Also, these firms are more likely to own generators compared to others. The computed predicted probability results for a ten-year-old metals firm are presented in figure 11 . We see that the probability of belonging to this high growth cluster almost doubles with generator ownership, and triples when the firm also uses email. The probability increases by another 50 percent when it has access to overdrafts. ${ }^{1}$

\footnotetext{
${ }^{1}$ The clusters do not look different when the 2 year growth variable is dropped and loss of sales is taken as the "effects" variable.
} 
Figure 14. Predicted probability of belonging to a high growth cluster (computed for a ten-year-old metals firm with 25 employees)

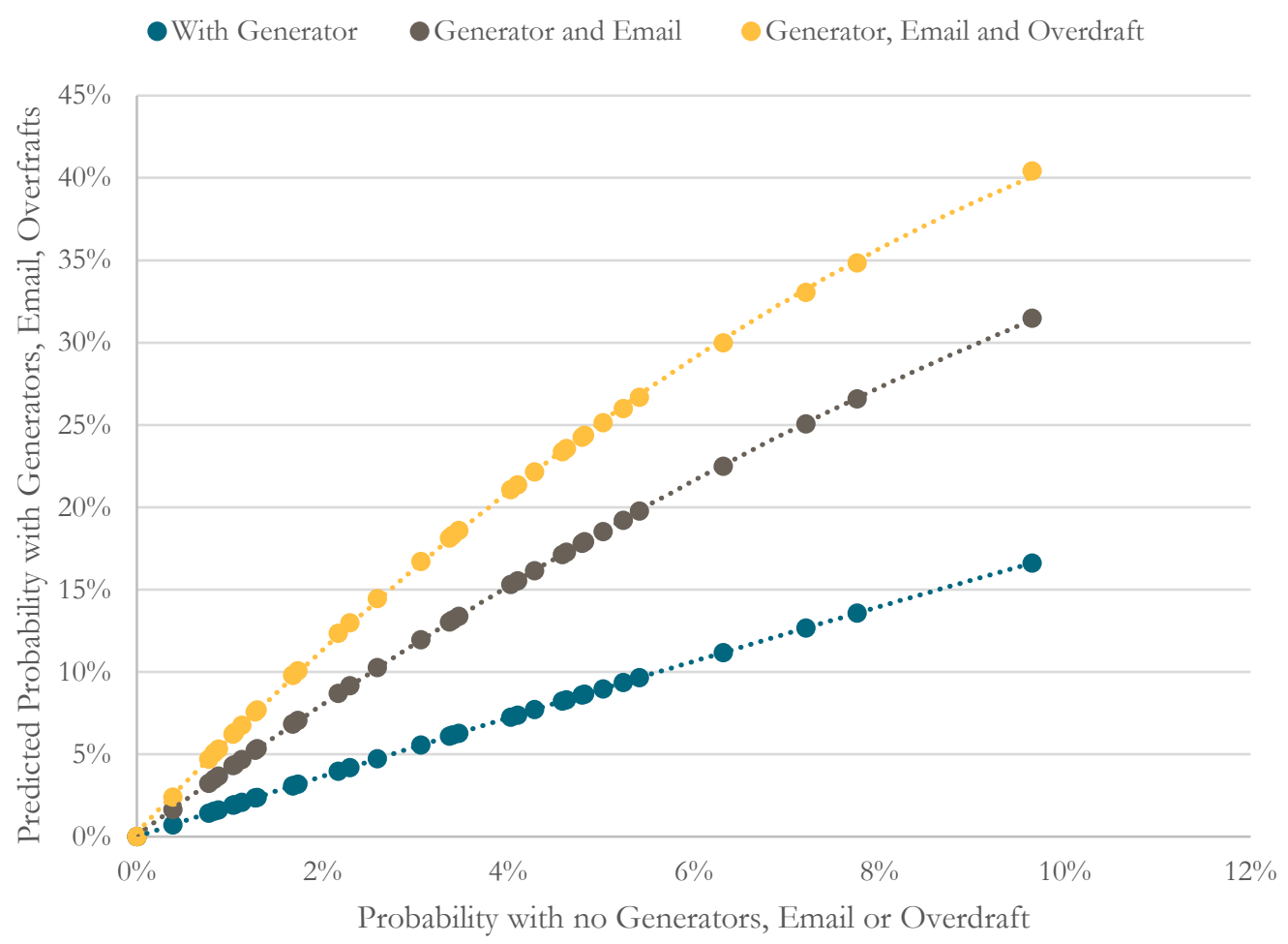

Cluster 3 points to a group of firms that seem to have succeeded by producing unique, differentiated products for niche markets (Table 1). The findings for this cluster may also reflect at least two endogenous responses to unreliable power: purchasing a generator, and only establishing a firm in sectors that promise good returns despite anticipated power problems. These possibilities are worthy of further exploration. 
Table 1. A sample of products manufactured by garment firms in Cluster 3.

\begin{tabular}{|c|c|c|c|c|c|}
\hline Country & Firm Age & Past Employment & Current Employment & Growth & Product (self reported) \\
\hline Botswana & 18 & 5 & 12 & $44 \%$ & Uniforms \\
\hline Botswana & 13 & 50 & 100 & $35 \%$ & Tents \\
\hline Ethiopia & 11 & 5 & 11 & $39 \%$ & men suit manufacturing \\
\hline Ethiopia & 6 & 12 & 21 & $28 \%$ & Leather shoe manufacturing \\
\hline Kenya & 20 & 10 & 20 & $35 \%$ & Weaving of rugs and carpets \\
\hline Kenya & 24 & 3 & 10 & $60 \%$ & Manufacturing uniforms \\
\hline Lesotho & 16 & 6 & 11 & $30 \%$ & $\begin{array}{l}\text { We Sew Wedding Dresses And Graduation } \\
\text { Gowns. }\end{array}$ \\
\hline Lesotho & 16 & 5 & 10 & $35 \%$ & $\begin{array}{l}\text { We Specialise In Making Fabric Seat } \\
\text { Covers. }\end{array}$ \\
\hline Liberia & 12 & 6 & 12 & $35 \%$ & African Dresses, Shirts, Trousers \\
\hline Malawi & 64 & 20 & 50 & $46 \%$ & $\begin{array}{l}\text { Manufacturing uniforms for security } \\
\text { companies }\end{array}$ \\
\hline Malawi & 14 & 6 & 12 & $35 \%$ & high shoe not just shoes \\
\hline Mozambique & 30 & 10 & 22 & $39 \%$ & Uniforms \\
\hline Nigeria & 11 & 3 & 11 & $65 \%$ & Showing clothes that is Tailoring \\
\hline Nigeria & 11 & 3 & 16 & $84 \%$ & design cloth \\
\hline Senegal & 7 & 4 & 15 & $66 \%$ & Producing traditional clothing \\
\hline South Africa & 18 & 19 & 42 & $40 \%$ & Uniforms \\
\hline South Africa & 6 & 15 & 30 & $35 \%$ & Shoes \\
\hline South Africa & 6 & 13 & 27 & $37 \%$ & Blankets \\
\hline Tanzania & 8 & 4 & 11 & $51 \%$ & Manufacturing batik \\
\hline Zambia & 5 & 4 & 10 & $46 \%$ & $\begin{array}{l}\text { Manufacturing footwear (leather shoes and } \\
\text { shoe accessories) }\end{array}$ \\
\hline Zambia & 4 & 12 & 25 & $37 \%$ & Processing of cotton wool from raw lint \\
\hline Zimbabwe & 8 & 25 & 149 & $89 \%$ & $\begin{array}{l}\text { Manufacturing Of Protective } \\
\text { Clothing,Casual Wear And School And } \\
\text { Work Uniforms }\end{array}$ \\
\hline
\end{tabular}




\section{Conclusion: Clustering Highlights the Varied Experiences of Firms in Africa}

Overall, the results indicate that investments in electricity are likely to improve firm productivity and contribute to job creation, if highly unevenly. If the firms currently on generators can switch to lower cost grid or off-grid power, the resources freed up will be available for investments that will enable firms to become larger and/or more productive.

The results also show that there is considerable heterogeneity in our sample. The first of the two largest clusters reveals that there are many firms within Africa (mostly in middle-income countries) which experience low costs, and negligible losses, even without generators. At the other end, there is a large group of firms in Africa which has generators-self-generation allows these firms to minimize losses, and to grow slowly.

The other clusters highlight the differential impact of electricity problems on firms, with clusters of firms experiencing extremely high outages and losses and negligible growth, sometimes even with generator use. However, a unique cluster of rapidly growing small firms demonstrates that all is not lost—some small firms with generators, technology use and financial access are able to grow even in an adverse business environment.

Further research can help shed light on various questions not addressed in this paper. Chief among them are the following - what is the financial burden of using a generator and how does it impact firm productivity and job creation? Do firms endogenize the problem of unreliable power by choosing certain production technologies over others? What does this mean for economic development and growth? Do firms choose to enter (or not enter) a country because of its power situation? And finally, how many firms are "missing" because of unreliable power? This could be explored at the macro level—for an entire economy—or at the micro level, by sector or type of firm. Understanding how firms cope with unreliable power is a critical to the design of polices to promote private sector development and economic growth. 


\section{Appendix 1: A Sample of the Literature on Electricity Access}

\section{Literature Reviews}

- Energy, Economic Growth, and Poverty Reduction (Robert Bacon and Masami Kojima, 2016).

o Seminal literature review of 200 studies on energy and growth.

- The Impact of Electricity Access on Economic Development: A Literature Review (ESMAP, GIZ, MBZ, 2013).

o Review of macro and micro-level research on the link between electricity and economic development.

- Is Electricity Supply a Binding Constraint to Economic Growth in Developing Countries? (Neil McCulloch and Dalia Zileviciute, 2016).

o Review of papers that used the World Bank Enterprise Surveys. Finds that over 40 percent of studies identify electricity as a binding constraint to growth.

- What are the links between power, economic growth and job creation? (Alberto Lemma et al., 2016).

o Findings: 1) energy plays a fundamental part in the economic growth process, 2) insufficient, unreliable, or costly access to power can be a binding constraint to businesses, 3) electricity is a binding constraint for all sizes of business.

- Coping with Blackouts: Power Outages and Firm Choices. Department of Economics, Yale University (M. M. Alam, 2013).

- Firms Operating under Electricity Constraints in Developing Countries. The World Bank Economic Review, 27(1), 109-132 (P. Alby, J-J Dethier, and S. Straub, 2013).

- Bring Back our Light: Power Outages and Industrial Performance in Sub-Saharan Africa (J.T. Mensah, 2016)

\section{Notable Sample Cross-Country Research using World Bank Enterprise Surveys}

- Power outages and firm performance in Sub Saharan Africa (Matthew Cole et al, 2018).

o Reducing electricity outage levels to those of South Africa would increase overall sales of firms in sub-Saharan Africa by 85 percent.

- Lobs! Electricity Shortages and Unemployment in Africa (Justice Mensah, 2018).

o Combines geodata on electricity transmission with Afrobarometer and WB Enterprise Survey data in Africa. Finds that electricity shortages exert a substantial negative impact on employment rates.

- The Role of Energy Capital in Accounting for Africa's Recent Growth Resurgence (Stephie Fried and David Lagakos, 2017). 
o Uses the UDI World Electric Power Plants Database and finds that energy capital investments accounted for around one third of Africa's growth resurgence since 2000 .

- Power Outages and Production Efficiency of Firms in Africa (Anselm Abotsi, 2016).

o Utilizes the World Business Environment Survey (early version of enterprise surveys), finds that the number of power outages experienced by a firm in Africa has a negative impact on production efficiency.

- How does electricity insecurity affect businesses in low and middle-income countries? (Andrew Scott et al., 2014).

o Electricity insecurity impacts productivity of manufacturing SMEs and investment in and by SMEs, but impacts are mixed and often statistically insignificant.

- The influence of services on firm productivity in sub-Sabaran Africa (Godfrey Madigu, 2014).

o Results show a significant relationship between the ownership of a generator, high power outages, and productivity.

- Africa's Private Sector: What's Wrong with the Business Environment and What to Do About It (Vijaya Ramachandran et al., 2009).

o Sub-Saharan African business people identify poor infrastructureparticularly the lack of a reliable source of power-as a constraint on private sector activity.

- Service Inputs and Firm Productivity in sub-Saharan Africa: Evidence from Firm-Level Data (Jens Arnold et al., 2006).

o Significant and positive relationship between firm productivity and service performance in three sectors (communications, electricity, and financial services).

\section{Sample of Recent Specific Country Research Using World Bank Enterprise Surveys and Other Databases}

- Power Outages, Its Economic Cost and Firm Performance: Evidence from Ethiopia (Lamessa Abdisa, 2018).

o Unreliable supply of electricity is the main constraint to doing business in Ethiopia; power outages were found to negatively affect firms' productivity, and outages are particularly costly for large firms.

- Electricity Cost and Firm Performance: Evidence from India (Ama Abeberese, 2017).

o Utilizes the Indian Annual Survey of Industries and finds that electricity constraints may lead firms to operate in industries with fewer productivityenhancing opportunities.

- The impact of electricity shortages on firm productivity: Evidence from Pakistan (Corbett Grainger and Fan Zhang, 2017).

o Utilizes data from the Pakistan Bureau of Statistics and finds that an increase in the incidence of power outages leads to significant decrease in a firm's total value of output and value added. 
- Electricity Load Shedding: An econometric analysis of the productivity of firms in the manufacturing sector in Lusaka (Yimbilanji Sichone et al., 2016).

o Load shedding has a negative and significant impact on the productivity of firms in the manufacturing sector in Zambia.

- The Value of Rural Electricity: Evidence from the Rollout of the U.S. Power Grid (Joshua Lewis and Edson Severnini, 2015)

o Farm access to electricity led to a 35 percent increase in productivity and families were willing to forgo 32 percent of annual income to live in an electrified home.

- Electric Power Outages and the Productivity of SMEs in Senegal (Lasana Cissokho and Abdoulaye Seck, 2013).

o Utilizes a Senegalese industry survey complemented by the WB Enterprise Surveys and finds that power outage frequency, duration and perceived severity have negative effects on scale efficiency.

- Do power cuts affect productivity? A case study of Nigerian manufacturing firms (Busani Moyo, 2012).

o Utilizes World Bank Investment Climate Surveys and finds that power outages have a negative and significant effect on productivity, particularly for small firms.

- Why are connection charges so high? an analysis of the electricity sector in Sub-Sabaran Africa (Moussa Blimpo et al, 2018).

o Estimates a model of household and electric utility behavior to describe how the low access rates and high connection charges that are common in the subSaharan Africa region arise from regulated electricity tariffs being set too low.

- Electricity Provision and Tax Mobilization in Africa (Moussa Blimpo et al, 2017).

0 Uses Afrobarometer data to show that tax morale increases with the provision of reliable power.

- How Do Electricity Shortages Affect Productivity? Evidence from India. American Economic Review, 106(3):587-624 (H. Allcott, A. Collard-Wexler, and S. D. O'Connell, 2016).

- Electricity Shortages and Firm Productivity: Evidence from China's Industrial Firms. Journal of Development Economics, 114:172-188 (K. Fisher-Vanden, E.T. Mansur, and Q.J. Wang (2015) 